\title{
O PROCESSO DE RETIFICAÇÃO DO RIO TIETÊ E SUAS IMPLICAÇÕES NA CIDADE DE SÃO PAULO, BRASIL
}

\author{
THE TIETÊ RIVER STRAIGHTENING PROCESS AND ITS IMPLICATIONS \\ IN THE CITY OF SÃO PAULO, BRAZIL
}

\author{
Denise Falcão Pessoa
}

\section{Resumo}

Este artigo trata do processo de retificação do Rio Tietê, em São Paulo, cujo estudo foi iniciado no fim do século XIX e busca detectar as principais implicações geradas por essa intervenção. Procura-se compreender como a retificação do Tietê atuou como parte do processo de urbanização acelerada, na qual os interesses imobiliários reforçaram os interesses da indústria automobilística recém-implantada, justificando a construção de avenidas marginais ao longo do rio retificado. No que diz respeito à ocupação do solo e à destruição da natureza, são discutidos equívocos e consequências desse processo, que acarretaram problemas urbanos e ambientais que perduram até os dias de hoje.

Palavras-chave: Rio Tietê. Drenagem Urbana. Retificação de Rio.

\section{ABSTRACT}

This paper deals with the straitening process of the Tiete river in Sao Paulo, Brazil, which began by the end of the XIX century. It aims to detect the implications generated by this intervention. This study also brings up the relation of the straightening of Sao Paulo's rivers and the implementation of the automobile industry and the investments in a road plan to justify the construction of expressways on the margins of the Tiete. It also speculates about the use of cars and the environment decay in the city due to the use of this type of transportation system. The article discusses mistakes that occurred in consequence of this process, concerning land occupation and the destruction of nature which implies in urban and environmental problems to these days.

Keywords: Tiete River. Urban Drainage. River Straightening. 


\section{INTRODUÇÃO}

A partir da segunda década do século XIX ocorreu a rápida urbanização da cidade de São Paulo, provocada pelo desenvolvimento da agricultura cafeeira no interior do estado. Rapidamente as terras urbanizáveis da cidade foram ocupadas até o limite das várzeas do Rio Tietê e de seus contribuintes Tamanduateí e Pinheiros.

O processo de industrialização ocorrido no início do século $\mathrm{XX}$ acelerou a expansão urbana e, posteriormente, em meados do século, a indústria automobilística se instalou, gerando a necessidade de ampliar o sistema viário. Esse crescimento desenfreado era visto como progresso e acreditava-se que todo desenvolvimento ocorria para benefício da população. Assim, as impactantes transformações do sítio urbano, como o desmatamento e as retificações e canalizações dos cursos d'água, encontravam justificativas na promessa de um progresso que melhoraria as condições de vida da população. Da mesma maneira que em muitas cidades mundo afora, somente a partir da década de 1960, e mais efetivamente no fim do século $X X$, começou-se a questionar até que ponto o desenvolvimento tecnológico traria benefícios para a sociedade como um todo.

É irônico recordar que o progresso técnico aparecia, desde os séculos anteriores, como uma condição para realizar essa sonhada globalização com a mais completa humanização da vida do planeta. Finalmente, quando esse progresso técnico alcança um nível superior, a globalização se realiza, mas não a serviço da humanidade. [...] A globalização mata a noção de solidariedade, devolve o homem à condição primitiva do cada um por si e, como se voltássemos a ser animais da selva, reduz as noções de moralidade pública e particular a um quase nada (SANTOS, 2002, p. 41).

A metrópole é a triste materialização dessa realidade. Este texto aborda questões relacionadas à retificação do Rio Tietê e seus afluentes sob a ótica dos interesses privados, de um lado, e da destruição da natureza de outro. O Rio Tietê, que na origem da cidade tem papel determinante, foi tratado ao longo do século
XX como um obstáculo para a urbanização. Sua várzea sofreu intervenções drásticas e o rio foi encurtado para quase metade do comprimento original ao longo do seu curso no município de São Paulo. Este artigo trata desse processo que congrega interesses imobiliários, desrespeito à natureza e descaso ao lazer da população.

\section{O Rio Tietê e o processo de urbanização de São Paulo}

Até o final do século XIX, segundo o censo de 1900, a cidade de São Paulo contava com cerca de 240 mil habitantes, ocupando a área circunscrita entre as várzeas dos rios Tietê, Tamanduateí e Anhangabaú. Dos primeiros anos de colonização do Brasil até o início do século XVIII São Paulo foi local de escambo, transações sem uso de dinheiro, o que dá ideia do pouco desenvolvimento da região. A atividade econômica resumia-se ao comércio de panos de algodão, mantimentos, carnes, cera e couro. Apenas em 1711 São Paulo foi elevada à categoria de cidade. Sua localização estratégica entre Minas Gerais e os campos de criação de gado no Sul e seu apoio às rotas de busca de riquezas, como o ouro, no interior do país eram suas características mais importantes.

No fim do século XVIII, com a produção de cana-de-açúcar, São Paulo passa a integrar o circuito do comércio colonial. Isto se reflete no aspecto da cidade:

As ruas que até então eram encaradas como continuação das casas, começaram a receber um tipo de acabamento que thes dava a condição de serem encaradas como lugar público. Em 1780, por exemplo, "se passou um edital para se fazer uma postura definindo que toda a pessoa que tiver carros dê cada vez uma carrada de pedras para se fazerem as ruas desta cidade". [...] Lentamente, delimitavam-se calçadas, ruas, becos e serventias, fixando-se também os limites da propriedade pública e privada, enquanto o Estado se erguia como elemento "neutro" administrador do novo espaço urbano (SEABRA, 1987, p. 27). 
Desde a década de 1870 as várzeas dos rios Tietê, Pinheiros e Tamanduateí configuraram-se limites naturais e históricos dessa expansão urbana, quando a cidade passou a ter crescimento acelerado e precisava expandir seu território para além da área central (Figura 1).

Desde essa época, as várzeas dos rios Tietê e Pinheiros, consideradas terrenos ruins para a construção, começaram a ser vistas como área com potencial para urbanização. Entretanto, seriam necessárias grandes obras de drenagem. O Tietê é um rio meândrico, sinuoso, com grande área de inundação e cheias frequentes. A principal atividade econômica que acontecia no

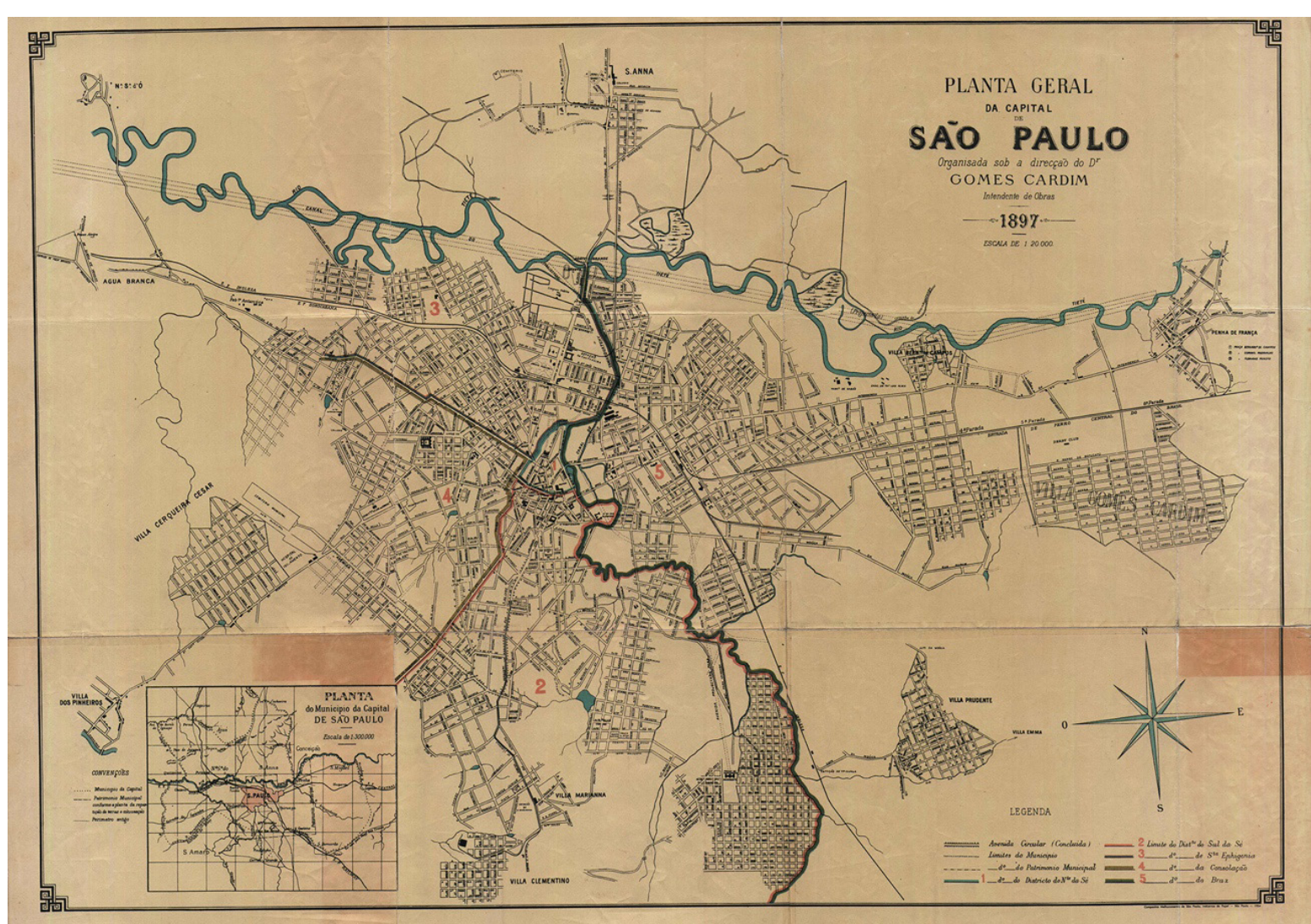

rio era a extração de areia. Sua várzea era pouco habitada. As raras casas do local sofriam com alagamentos anuais que traziam lixo, um odor desagradável e consequentemente doenças que se propagavam facilmente. Em decorrência desses fatos, os moradores da várzea eram chamados de varzeanos, termo pejorativo usado para nomear as áreas mais pobres e sujas da cidade. Na várzea também aconteciam atividades de lazer, sobretudo o futebol, esporte introduzido no Brasil no final do século XIX (SILVA, 2015, p. 294) que chegou a contar com mais de mil campos na primeira metade do século $X X$.
Figura 1 - Planta geral da capital de São Paulo, 1897, organizada sob a direção de Gomes Cardim. A planta mostra a área urbanizada da cidade.

Fonte: (CARDIM, 1954). 
Somando-se à demanda por áreas de expansão urbana, havia também problemas graves de saneamento a solucionar. Ainda que o principal motivo para a ocupação da várzea fosse a expansão urbana, a justificativa mais frequente para a retificação do rio era a prevenção de eventos epidêmicos que ocorriam repetidamente, como varíola, morfeia, febre amarela, cólera, tuberculose, peste bubônica e a gripe espanhola que atingiu a cidade em 1918 (BERTOLLI FILHO, 2003).

Embora a nascente do Rio Tietê esteja a apenas $22 \mathrm{~km}$ do Oceano Atlântico, o rio cruza a bacia sedimentar de São Paulo. Seu curso atravessa o planalto Atlântico em direção ao interior. "Antiga depressão formada pelo afundamento de enormes blocos rochosos através de movimentos predominantemente verticais. Essa depressão foi logo sendo preenchida por sedimentos trazidos pelo Tietê e seus afluentes" (OHTAKE, 1991, p. 36).

Nas grandes e largas calhas aluviais do Tietê e Pinheiros, assim como ao longo de alguns de seus afluentes principais, existiam antes dos serviços de retificação, redes de drenagem típicas de planícies de soleira, fortemente, submersíveis. Dominava, de Osasco a Mogi das Cruzes, no vale do Tietê, assim como no Pinheiros, drenagem extremamente sinuosa, com meandros divagantes, labirínticos. Em vários pontos, devido à profusão de meandros, lagoas de meandros, ilhas fluviais estabelecidas em antigos meandros de pedúnculos cortados, assim como ligeiros trechos de drenagens anastomosadas, era possível reconhecer-se uma drenagem divagante labiríntica (AB'SABER, 1958, p. 78).

O Rio Tietê foi formado no período de aproximadamente 12 milhões de anos, sobre terrenos de 20 milhões de anos em seus trechos mais recentes.

O relatório apresentado pela Comissão de Melhoramentos do Rio Tietê (criada em 1924) expõe seu comportamento. Originalmente, fora da época das chuvas, o Tietê tinha velocidade moderada. No verão, o aumento no volume de água aumentava a velocidade das águas, provocando a erosão do leito que, ao longo do tempo, gerava meandros formados pela retirada de terreno aluvial.
Frequentemente, após enchentes, o rio mudava seu curso, traçando um novo desenho e formando ilhas.

A rápida expansão da cidade de São Paulo foi marcada, desde o início, por forte especulação de terras. A legislação fundiária no Brasil, no fim do século XIX, regulamentada pela Lei de Terras, de 1853, não restringia o peso da propriedade da terra urbana, através de cobrança de impostos maiores para terrenos não edificados, por exemplo. Em países como França, Itália, Argentina e Estados Unidos, a legislação fundiária reconhecia a valorização das propriedades urbanas decorrente dos investimentos públicos e buscava restringi-la, coibindo a especulação, isto é, lançando tributos sobre as propriedades. No Brasil, a propriedade fundiária urbana valorizou-se, no processo de produção da cidade, sem encontrar obstáculos. Odette Seabra interpreta esse processo como consequência da ausência de interesses conflitantes entre os diversos segmentos da sociedade:

Enquanto em outros países apareceu claramente que a legislação era em si mesma a conformação de um conflito de interesses, no Brasil e mais especialmente no caso de São Paulo, a falta de uma legislação pode estar indicando uma superposição de papéis. Ou seja, proprietários rurais são ao mesmo tempo proprietários urbanos e legisladores nas assembleias. De modo que, a formação de um circuito urbano avantajado de apropriação de mais valia social não Ihes teria causado nenhum pânico (SEABRA, 1987, p. 21).

Já no fim do século XIX estudava-se a retificação dos rios Tietê e Pinheiros, sob a justificativa de higienizar a cidade. Os primeiros registros mostrando a conveniência da drenagem da várzea do Tietê datam de 1866 e apontam a intenção de usar esse terreno para o crescimento da cidade. Os primeiros projetos de retificação dos rios na cidade de São Paulo foram realizados a partir de 1842. O primeiro rio a ser retificado na cidade foi o Tamanduateí, cuja obra terminou em 1841 (JORGE, 2017, p. 25).

Nessa época os rios também eram usados para a prática de esportes, com clubes instalados nas suas margens. Era o caso do Clube Pinheiros (nessa época chamado de Germânia) no Rio 
Pinheiros, do Clube de Regatas do Tietê, da Associação Atlética de São Paulo e do Clube Esperia no Tietê, que evidenciavam o uso da várzea voltado ao lazer, antes da urbanização. A competição de natação do Rio Tietê era a mais popular; iniciava na Ponte da Vila Maria (hoje Ponte Jânio Quadros) e terminava na Ponte Grande. Essas competições de remo e natação foram realizadas até a interrupção, em 1944, por causa das águas que já estavam poluídas e, por isso, inadequadas para tais usos (JORGE, 2017, p. 174).

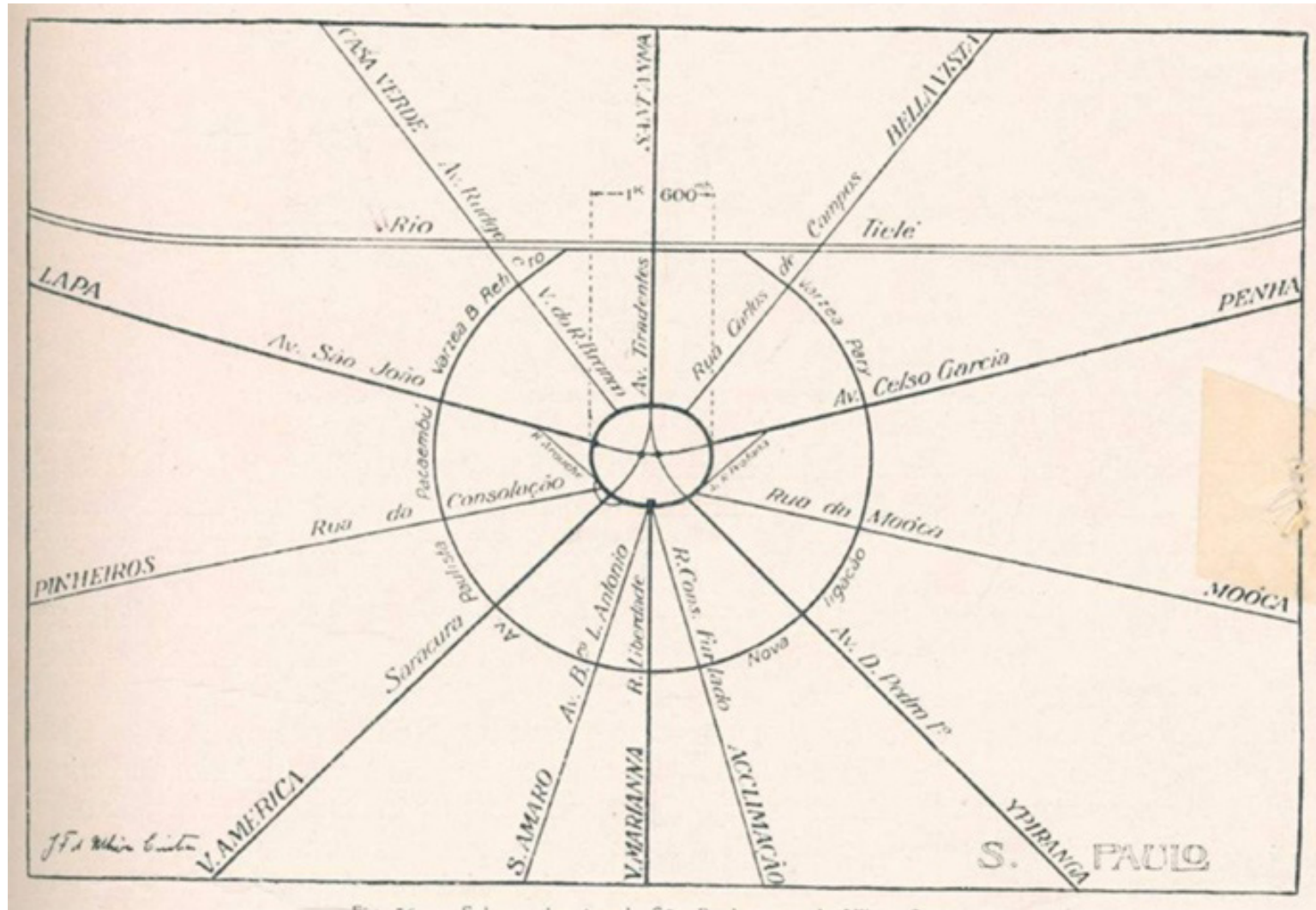

\section{Estudos para a Retificação dos rios Tietê e Pinheiros}

Na gestão municipal de José Pires do Rio, em 1930, é publicado o Estudo de um Plano de Avenidas por Francisco de Prestes Maia. João Florence de Ulhôa Cintra era o chefe da Comissão de Melhoramentos do Rio Tietê desde 1927. Nesse estudo, Prestes Maia apresenta o plano radio-concêntrico para a cidade, baseado nos planos de Paris, Berlim e Moscou, entre outros (Figura 2). Expõe referências dessas cidades, mostrando levantamentos de vários aspectos, como a largura das vias
Figura 2 - Diagrama do Plano de Avenidas.

Fonte: (MAIA, 1930). 
principais e secundárias e a configuração de calçadas. Estuda em detalhe o sistema de transporte ferroviário, metroviário, tram, ônibus e automóveis de muitas cidades europeias e americanas, buscando soluções para garantir a boa circulação de veículos, evitando congestionamentos. A ênfase do plano é o sistema viário e a circulação de veículos, sem perder de perspectiva o embelezamento da cidade. Menciona sempre a importância dos monumentos e das referências visuais, dos passeios públicos e da fruição dos pedestres.

Defende também a ideia de que o centro deve ter facilidade de comunicação em todas as direções. Propõe adaptações

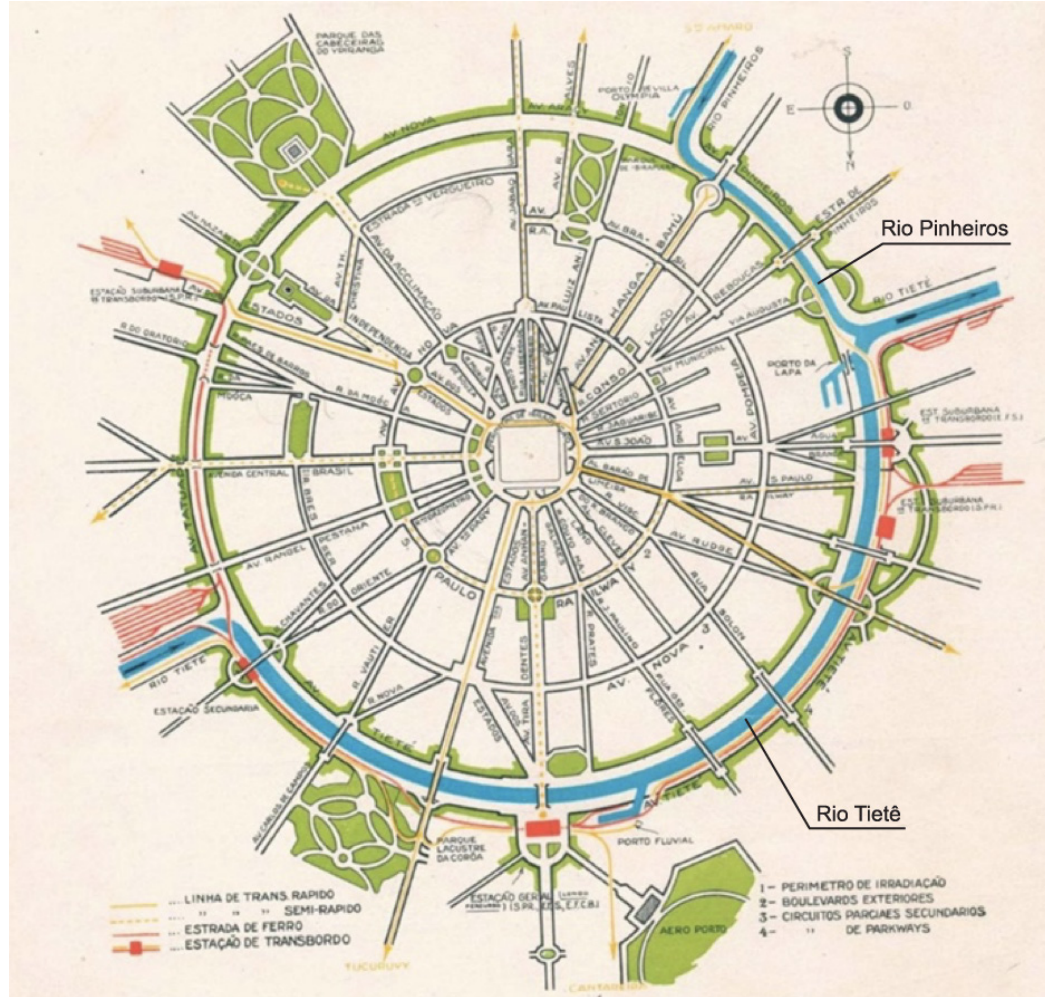

Figura 3 - Diagrama do Plano de Avenidas. Fonte: (MAIA, 1930). ao sistema viário existente, sempre que possível, evitando desapropriações custosas que só beneficiariam gerações futuras.

A ligação do sistema de vias radiais se dá através de anéis viários concêntricos ao centro da cidade: as perimetrais. Essas vias conectam os bairros. A perimetral mais externa é definida a norte pelo Tietê e a oeste pelo Pinheiros, onde haveria avenidas nos moldes das avenidas marginais ao Rio Sena em Paris (Figura 3).

Até o final da década de 1930, pouco do plano avançou em relação à implantação do Plano de Avenidas. Seis meses após o golpe do Estado Novo, Prestes Maia foi nomeado prefeito de São Paulo pelo então governador, Adhemar de Barros. Só a partir daí o Plano de Avenidas foi usado como diretriz para o desenvolvimento da cidade. Foram realizadas as avenidas Anhangabaú e Itororó - hoje Avenida 9 de Julho - 23 de Maio e Avenida Prestes Maia, o eixo Consolação-Rebouças, a Radial Leste, entre outras. As avenidas perimetrais Tietê e Pinheiros, como concebidas no plano, um bulevar ao longo do rio, não chegaram a ser executadas.

Outro estudo que recomendou a retificação do Rio Tietê, o saneamento e a urbanização da várzea, foi o relatório Moses, realizado pelo IBEC (International Basic Economy Corporation) em 1950, na administração de Lineu Prestes, nomeado pelo então governador, Adhemar de Barros. O estudo era dirigido por Robert Moses, engenheiro e advogado nova-iorquino, que tinha ampla experiência em planejamento urbano em Nova York. O relatório propõe o desenvolvimento do subúrbio, conectado ao centro por vias expressas, sem cruzamentos em nível, modelo adotado nos Estados Unidos. Recomenda que a retificação do Rio Pinheiros fosse feita pela Light, numa parceria público-privada na qual a Light receberia pelos seus investimentos uma porção de terra ao longo do rio. Esse tipo de parceria era uma inovação que já havia sido testada na América do Norte (SOMEKH; MALTA, 2002, p. 85).

A drenagem da várzea e a retificação dos rios possibilitavam a criação de terra urbanizável com amplas oportunidades de lucro para os investidores. Na época não havia legislação e 
cobrança de impostos que inviabilizassem o acúmulo de terrenos desocupados por um mesmo proprietário, o que favorecia a especulação imobiliária.

A Comissão de Melhoramentos do Rio Tietê, criada com o intuito de estudar e propor soluções para os problemas das cheias dos rios Tietê e Pinheiros, apresentou o projeto de retificação do Rio Tietê, coordenado pelo engenheiro sanitarista Francisco Saturnino Rodrigues de Brito, que incluía um parque e dois lagos de um milhão de metros quadrados de superfície cada, para controle do nível das águas (Figura 4). Esse projeto não foi executado e, em 1929, Saturnino de Brito apresentou à
Prefeitura de São Paulo relatório do plano de regularização dos rios Tietê e Pinheiros. Nesse relatório ele critica a falta de estudos hidrológicos mais aprofundados e a interrupção das observações iniciadas pela Comissão de Saneamento em 1893, chefiadas pelo engenheiro José Antônio da Fonseca Rodrigues.

Embora a drenagem da várzea do Tietê fosse urgente, por conta da insalubridade da área, as obras de retificação foram adiadas em vários momentos. A crise mundial de 1929 e a revolução de 1930 impediram seu início. A partir de 1937, João Florence de Ulhôa Cintra foi responsável pelos estudos de retificação do Tietê e seu projeto, batizado de Projeto Cintra, foi executado,

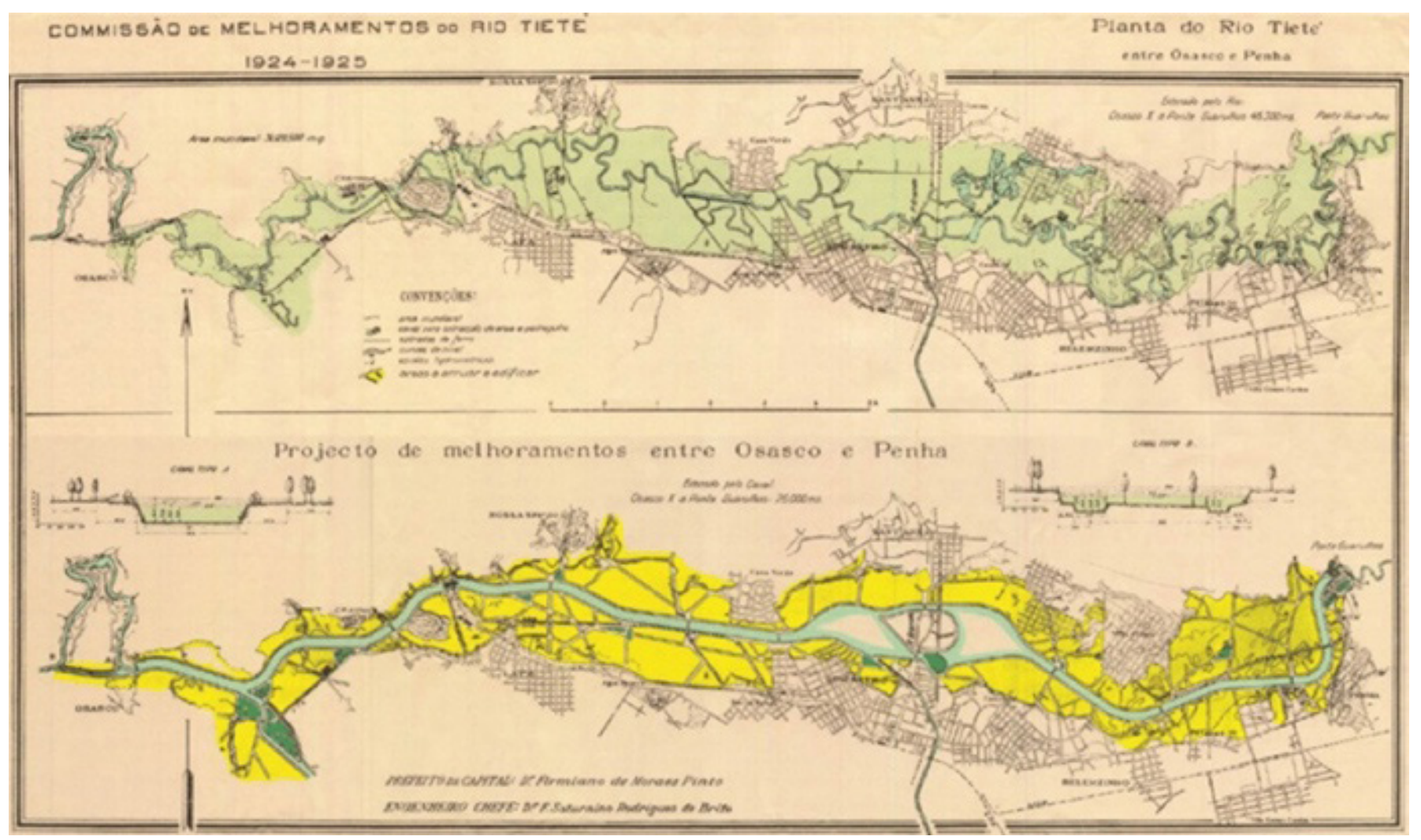

Figura 4 - Projeto realizado por Francisco Saturnino Rodrigues de Brito para o Rio Tietê. Fonte: (TOLEDO, 1996) 
com a realização das obras nas décadas de 1950 e 1960 . O projeto previa a canalização e o aprofundamento de 4 metros da cota do rio no trecho entre Guarulhos e Osasco, ou seja, no trecho do rio que está dentro do município de São Paulo. Os dois diques propostos por Saturnino de Brito não foram executados, pois, segundo Cintra, eles poderiam se romper, causando uma enchente devastadora.

\section{As obras de RETIFICAÇÃo dos RIOS TIETÊ E PINHEIROS}

A obra de retificação do Tietê foi realizada com recursos públicos. A área da várzea foi, ao longo do tempo, sendo usada para projetos de interesse público, como o Terminal Rodoviário do Tietê, os acessos às pontes e a construção da Santa Casa (hoje ocupada pelo Tribunal Criminal da Barra Funda), mas também para outros fins, como o caso do Centro de Convenções e Eventos Anhembi.

A retificação do Rio Pinheiros tinha como principal objetivo produzir energia elétrica. Suas obras ficaram a cargo da companhia canadense The São Paulo Tramway Light and Power Company Limited, conhecida como Light, que já produzia energia elétrica em São Paulo. A Light recebeu, em troca da execução do trabalho, as terras abaixo da cota máxima de inundação do Rio Pinheiros e pôde negociá-las livremente. Após a retificação, até o governo do estado de São Paulo teve que adquirir terras da companhia, para executar o projeto das marginais e da Ceagesp (Companhia de Entrepostos e Armazéns Gerais de São Paulo) (SEABRA, 1987, p. 174).

A retificação dos rios era considerada a melhor alternativa para solucionar os problemas de enchentes e de insalubridade das várzeas. Indubitavelmente, essa alternativa era a que mais favorecia a Light, pois seu investimento seria altamente recompensado.

Alternativas poderiam ter sido adotadas Diante do rápido crescimento da população urbana de São Paulo e da emergência de obras de saneamento da várzea. Seria possível drenar a várzea dos rios sem alterá-los drasticamente. Outra possibilidade seria criar um sistema de coleta e tratamento de esgoto adequado, e concomitantemente, adensar a área urbana existente, deixando a várzea desocupada. Cabe lembrar que a cidade tinha nessa época densidade muito baixa e, mesmo com o crescimento acelerado ocorrido no início do século $X X$, manteve densidade muito aquém da encontrada em outras metrópoles. Outra possibilidade seria alterar a lei fundiária, para impedir a valorização das terras da várzea e, assim, sua especulação (LANGENBURCH, 1971).

A questão da drenagem da várzea apresentava interesses incompatíveis. Para que o solo estivesse sempre drenado, era necessário manter os rios e as barragens em nível muito baixo. Entretanto, para a geração e comercialização de energia, a Light pretendia manter as barragens sempre cheias.

Em seu relatório, Saturnino de Brito chama a atenção para a influência das represas da Light sobre o regime do rio, recomendando o rebaixamento de um metro da cota máxima da Barragem de Paraíba.

Uma possibilidade técnica de regularização do regime do rio poderia ser a de reter parte do volume de água nas cabeceiras por ocasião das chuvas, para liberá-las, paulatinamente, nos outros meses do ano. O que, de qualquer forma, não suprimiria obras no leito do rio, mas poderia torná-las menos onerosas. Essa possibilidade chegou a ser discutida, e mesmo a Companhia Light, interessada na montagem do sistema hidrelétrico de São Paulo, teria conseguido em 1925 uma concessão para efetuar esses represamentos. Abandonou esse projeto, definindo-se por outra alternativa (SEABRA, 1987, p. 27).

O Decreto $n^{\circ} 4.487$ de novembro de 1928 concedia à Light as terras da várzea do Rio Pinheiros, estabelecendo que a área concedida fosse correspondente à máxima de cheia. Não existiam registros da cota máxima do rio, sendo necessário, portanto, delimitar a cota de inundação dos rios Pinheiros e Tietê. Para tanto, foi usada a enchente ocorrida pouco tempo depois, em 
fevereiro de 1929, a pior de todos os tempos, na qual as águas atingiram o nível de 720,55 metros na Ponte das Bandeiras, no Rio Tietê e na foz do Pinheiros, cotas nunca antes relatadas. A cota máxima registrada até então era de cerca de $719,80 \mathrm{~m}$. Ao que tudo indica, essa cheia foi manipulada de forma criminosa pela Light, com o intuito de garantir uma vasta área de várzea e consequente valorização dos investimentos da companhia (SEABRA, 1987, p. 54).

As chuvas foram intensas na cidade de São Paulo no início de 1929. No entanto, no mês de fevereiro, quando ocorreu a grande cheia dos rios Tietê e Pinheiros, a precipitação foi menor do que em janeiro. A chuva ocorrida na primeira metade do mês de fevereiro não apresentara níveis preocupantes, sobretudo nos dias que antecederam as cheias. No período entre os dias 15 e 20 houve uma estiagem, com dias ensolarados. $O$ dia em que se registrou a maior cheia foi 18 de fevereiro, alguns dias depois do término das chuvas. Mesmo com vários dias seguidos de sol o nível das águas permanecia alto (SEABRA, 1987, p. 55).

A enchente dos rios Tietê, Tamanduateí e Pinheiros atingiu os bairros ao longo dos rios. Centenas de famílias foram obrigadas a abandonar suas casas. O cenário era desolador. Tudo levava a crer que a enchente era provocada pelas represas da Light. As manchetes dos jornais destacavam este fato, como é o caso do jornal O Estado de S. Paulo de 16 de fevereiro de 1929, que dizia: "As águas das represas da Light invadem Santo Amaro" (nessa época, Santo Amaro era município vizinho de São Paulo). A Light não se pronunciava a respeito:

O silêncio da Companhia Light, embora assustador, tem também uma lógica. Se algumas discussões fossem travadas, muito facilmente se faria correlações entre o Decreto 4487 de 9 de novembro de 1928 e a necessidade que tinha a Companhia de demarcar no terreno o limite da sua jurisdição. Pela cláusula XX do D. 4487: "antes, porém de realizar as obras de canalização do Rio Pinheiros e seus afluentes, deverá a Companhia submeter à aprovação do Governo a planta da área a desapropriar com indicação dos seus limites, bem como o projeto detalhado das obras de saneamento ou dos benefícios a realizar nesta área". [...] Esta parece ser a questão fundamental, garantir-se de uma superfície do terreno nas várzeas tão ampla quanto possível, sobre a qual exerceria os direitos contidos na Concessão que obtivera. [...] O que de fato acontecera é que no segundo dia de chuvas (dia 14), as represas que estavam cheias foram abertas e a partir da região de Santo Amaro, propagou-se uma onda de cheias que se sobrepôs às águas já existentes nas várzeas do Pinheiros e alcançava, por efeito retardado, o rio Tietê (SEABRA, 1987, p. 191).

A Companhia City, empresa loteadora inglesa, responsável por vários projetos de parcelamento do solo na cidade e pela criação de bairros como Jardim América e Jardim Europa, proprietária de terras desapropriadas, questionou a demarcação da Light. A companhia questionou a legalidade do uso da cota máxima da cheia de 1929 e também levantou a suspeita de que a enchente pudesse ter sido provocada. Mais tarde, fez um acordo com a Light, obtendo parte das terras desapropriadas.

A Light teve ganho significativo pelo seu investimento, pela cobrança da energia produzida e venda das terras, valorizadas pelas obras de retificação do Pinheiros, que as drenaram e sanearam. Além disso, lucrou com o crescimento da cidade, que passava por momento de grande expansão (PESSOA, 2006, p. 115).

\section{A IMPLANTAÇÃO DAS AVENIDAS MARGINAIS DO Tietê e Pinheiros}

O início das atividades da indústria automobilística no Brasil deuse concomitantemente ao planejamento da drenagem do Tietê e à implantação do plano rodoviário nacional, iniciado no governo Dutra em 1945, quando São Paulo contava com população de aproximadamente um milhão de habitantes. Nessa época, predominava o transporte coletivo na cidade, sobretudo bondes, e os automóveis escassos. A população da cidade foi crescendo rapidamente, atingindo 4,7 milhões de habitantes no ano de 1960 e 8,2 milhões ao longo dessa década. 
O plano rodoviário incentivaria a aquisição de carros particulares e, em 1968, o Governo Federal criou legislação para a aquisição de carros através de consórcio, garantindo, com isso, o escoamento da produção de veículos. A implantação da indústria automobilística no Brasil ocorre nesse cenário e já tem clara, desde seu início, a perspectiva de tornar a aquisição do automóvel acessível a uma fatia considerável da população.

A industrialização iniciou-se de forma concentrada na cidade de São Paulo e em cidades adjacentes, que foram rapidamente crescendo e formando uma única mancha urbana. A produção automobilística escoava, sobretudo na área onde era produzida, acarretando grande impacto na cidade de São Paulo, cuja malha viária não comportava o grande aumento de veículos em circulação.

As várzeas dos rios, agora supostamente livres das enchentes, eram possibilidades de ligações de leste e oeste de São Paulo - no caso da várzea do Tietê - e de norte e sul - no caso da várzea do Pinheiros. Os rios, que até então eram considerados um estorvo por quem tomava as decisões do desenho da cidade, serviriam para implantar o sistema viário, conectando os extremos do município de São Paulo.

As vias foram implantadas muito próximas dos canais, sem deixar áreas livres que pudessem ser usadas como áreas de usufruto dos rios (Figura 5). Assim, os rios ficaram confinados entre avenidas expressas, sem qualquer condição de utilização pela população para usos mais nobres como há menos de 100 anos parecia ser sua vocação: a prática de esportes, a pesca, o lazer.

\section{IMPACTOS AMBIENTAIS DECORRENTES DA RETIFICAÇÃO}

Com a retificação dos rios, os mais de mil campos de futebol berço da cultura do futebol brasileiro -, os clubes de regatas e os barcos foram desaparecendo por causa da força da industrialização, da necessidade de geração de energia elétrica, da imposição do escoamento da produção industrial e das pistas

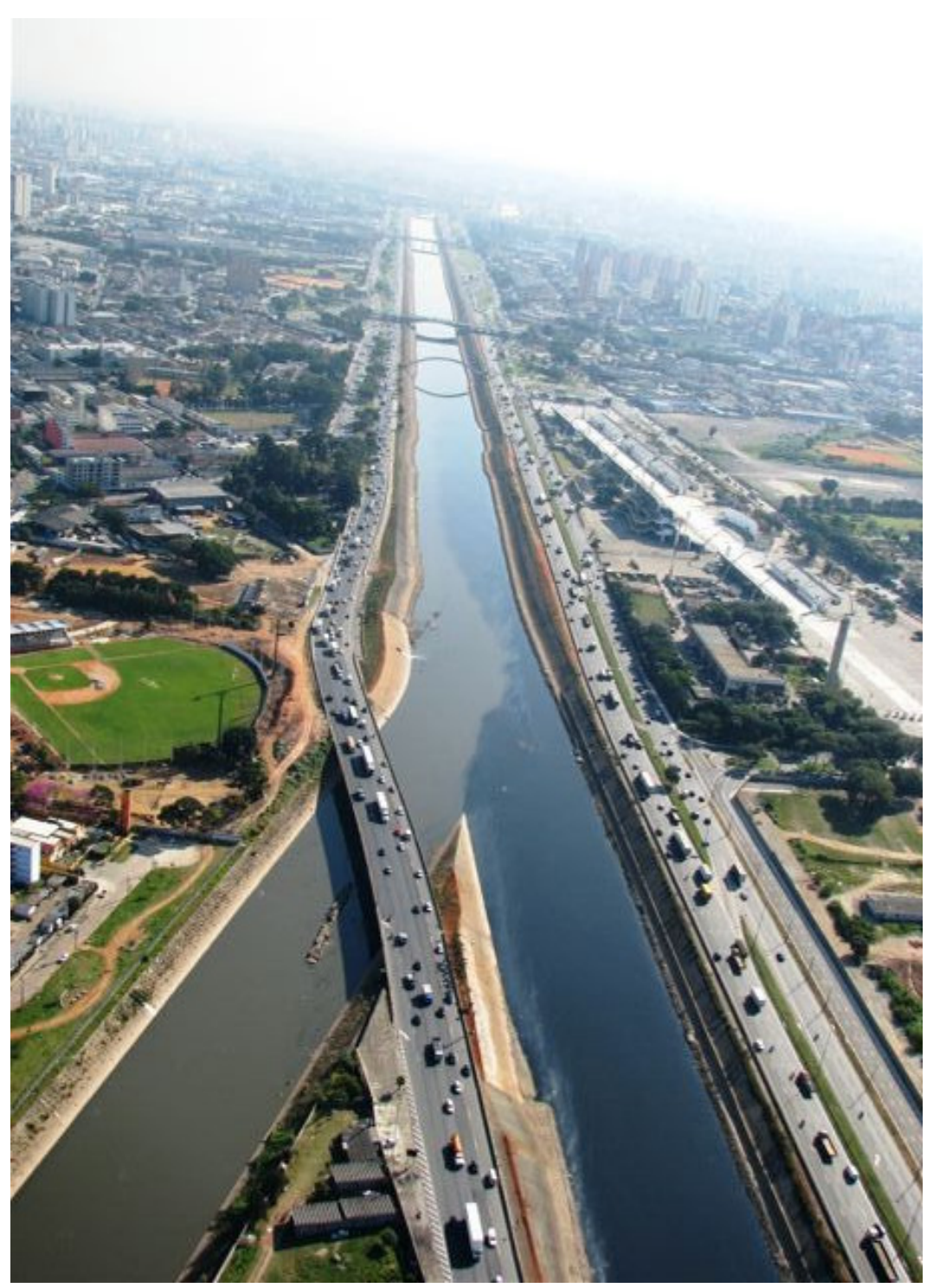

Figura 5 - Encontro do Rio Tamanduateí e do Rio Tietê, mostrando a avenida marginal do Tietê.

Fonte: Foto de Agnaldo Bertolo, 2008. 
de alta velocidade, que ligavam as várias estradas que partem da cidade de São Paulo.

Apesar da retificação e do aumento da calha do Rio Tietê, as inundações continuaram a ocorrer. Em 1963 foi constituída comissão parlamentar com o intuito de avaliar os trabalhos de retificação. $O$ assoreamento do rio foi um problema que se apresentou ainda durante a construção do canal, que recebia grandes volumes de dejetos.

O prejuízo ambiental causado pela retificação do Tietê é intenso. Por um lado, devido ao bota-fora do material retirado, que constitui problema de grande magnitude; por outro, os problemas gerados por essa prática, como o custo do transporte dos detritos do rio e a deterioração ambiental da área onde esse material é descartado.

Em São Paulo, ocorre acelerado crescimento urbano que agrava a deterioração do meio ambiente. As novas construções impermeabilizam total ou parcialmente o solo, e as águas de chuva, que antes eram em parte infiltradas no solo, passam a ser levadas diretamente aos cursos d'água.

A população, que no início das obras de retificação era de cerca de um milhão de habitantes, foi se multiplicando até chegar aos mais de 12 milhões de hoje (INSTITUTO BRASILEIRO De GEOGRAFIA E ESTATÍSTICA, 2019). Ela presenciou passivamente transformações e perdas, sem se dar conta da degradação urbana que ocorria a sua volta.

Em 1999, a cidade de São Paulo chegou à relação de dois habitantes por veículo, contabilizando mais de cinco milhões de veículos. Os investimentos dos governos estadual e municipal em transporte público têm sido insuficientes. São Paulo ainda hoje não possui a rede de metrô completa, contando apenas com poucas linhas, insuficientes para o transporte da população.

A área urbana segue crescendo. O valor da propriedade em áreas dotadas de boa infraestrutura continua aumentando, o que obriga as pessoas a morar na periferia, tornando o automóvel mais e mais desejável. Grande parte dos percursos se dá nas marginais do Tietê e do Pinheiros, o que impede vislumbrar a possibilidade de recuperação dos rios.

Após a retificação do Tietê, a velocidade das águas foi aumentada, pois os meandros, desaceleradores naturais, foram eliminados. Além disso, o aumento de velocidade das águas assoreia o rio por conta do material trazido, o que faz com que a calha seja diminuída, favorecendo as enchentes. Ou seja: o rio busca voltar ao traçado original, escolhido pela natureza. Mudar sua condição natural provoca desequilíbrio ambiental, pois o rio estará sempre tentando retomar o percurso definido ao longo de milhões de anos. $O$ desassoreamento do rio precisa ser feito ininterruptamente para não agravar o problema causado pelas cheias. As obras de retificação foram feitas para drenar a várzea, o que, no entanto, não foi plenamente alcançado até hoje.

O projeto de retificação do Tietê executado, logo após ser construído, ficou com vazão insuficiente. A vazão original do rio era de $330 \mathrm{~m}^{3} / \mathrm{seg}$, atingindo $440 \mathrm{~m}^{3} / \mathrm{seg}$ depois das obras de retificação. Em 2002 iniciou-se obra para aumentar a calha do rio, resultando na vazão de $1048 \mathrm{~m}^{3} / \mathrm{seg}$ (O ESTADO DE S. PAULO, 2002). Nessa obra, além do aumento da calha do rio, foi construída uma eclusa na barragem móvel sob o Cebolão, complexo viário sobre a confluência dos rios Pinheiros e Tietê. A vazão de água no Tietê segue crescendo e, com ela, crescem os problemas urbanos.

Quase que a totalidade do município de São Paulo está dentro da bacia do Rio Tietê. Antes da retificação, o rio recebia a contribuição das chuvas da sua bacia e parte do esgoto da área metropolitana de São Paulo. Grandes quantidades de águas da chuva eram absorvidas pelo solo, visto que a cidade tinha grande área permeável, com muitas ruas sem calçamento, terrenos baldios, jardins nas casas etc., de forma que a água da chuva chegava ao rio basicamente na mesma quantidade que o rio recebia em seu estado original.

Hoje a população de São Paulo passa de 12 milhões e não há critérios eficientes de planejamento ambiental. As construções foram feitas impermeabilizando quase a totalidade da área dos 
lotes. A pavimentação das ruas também diminuiu drasticamente a área permeável da cidade. Portanto, grande porção da água de chuva, antes absorvida pelo solo, passou a desaguar diretamente e mais rapidamente nos cursos d'água da cidade. O crescimento urbano teve outra consequência impactante: a captação de água para abastecer a cidade em outras bacias, mais distantes. O Rio Piracicaba, fora do município de São Paulo, fornece cerca de metade da água consumida. Essa água é esgotada no Rio Tietê, aumentando consideravelmente sua vazão. Esses fatores somados levaram a problemas ambientais e a danos irreversíveis.

\section{Considerações finaIS}

A ocupação mais intensa da cidade e a não existência de contraponto que equilibre a força do mercado imobiliário e os interesses da sociedade, bem como a ausência de interesses conflitantes entre legisladores e empreendedores da construção civil, constituíram cenário favorável à obtenção de lucros sem encontrar barreiras que impedissem sua livre ação. A especulação imobiliária, exercida, sobretudo pela Companhia Light, beneficiou-se dessa situação de falta de interesses antagônicos e da conivência do Estado. Da mesma maneira, a indústria automobilística, recém-criada na época da retificação do Tietê, exerceu grande influência sobre a urbanização das várzeas, criando desenho compatível com o uso do automóvel e, consequentemente com o escoamento da produção de carros.

A ausência de preocupação com o impacto ambiental e paisagístico de obras, como as marginais do Tietê e Pinheiros, frequente nas cidades em processo de industrialização do século passado, contribuiu para que não houvesse valorização da integração da cidade com os rios na escala humana, onde as pessoas pudessem continuar usufruindo do contato direto com suas margens, o que foi originalmente, aspecto tão valorizado na vida de São Paulo. Esse desenho equivocado tem consequências negativas até o presente, pois praticamente impossibilita outro desenho que permita o acesso das pessoas aos rios para uso de sua várzea como área de lazer e de contato com a natureza.

\section{ReferênCIAS Bibliográficas}

AB'SABER, Aziz Nacib. Geomorfologia do sítio urbano de São Paulo. São Paulo: USPFFCL, 1958.

BERTOLLI FILHO, Cláudio. A gripe espanhola em São Paulo, 1918: epidemia e sociedade. São Paulo: Paz e Terra, 2003.

CARDIM, Gomes (org.). Planta geral da capital do estado de São Paulo. São Paulo: Comissão do IV Centenário, 1954. Escala 1:20.000. Disponível em: http://www.arquiamigos.org.br/info/info20/i-1897.htm. Acesso em: 3 jun. 2019.

O ESTADO DE S. PAULO, São Paulo, 16 fev. 1929.

O ESTADO DE S. PAULO, São Paulo, 31 out. 2002.

INSTITUTO BRASILEIRO DE GEOGRAFIA E ESTATÍSTICA. IBGE Cidades: São Paulo. Rio de Janeiro, 2019. Disponível em: https://cidades.ibge.gov.br/brasil/sp/sao-paulo/panorama. Acesso em: 20 dez. 2019.

JORGE, Janes. Tietê: o rio que a cidade perdeu. São Paulo, 1890-1940. São Paulo: Secretaria do Verde e Meio Ambiente, 2017.

LANGENBURCH, Juergen Richard. Estruturação da grande São Paulo: estudo de geografia urbana. 1971. Tese (Doutorado em Geografia) - Faculdade de Filosofia, Ciências e Letras, Universidade de Campinas, Rio Claro, 1971.

MAIA, Francisco Prestes. Estudo de um plano de avenidas para a cidade de São Paulo. São Paulo: Companhia Melhoramentos de São Paulo, 1930

OHTAKE, Ricardo. O livro do Rio Tietê. São Paulo: Estúdio Ro Projetos e Edições, 1991.

PESSOA, Denise Falcão. Utopia e cidades: proposições. São Paulo: Annablume, 2003. SANTOS, Milton. Por uma outra globalização: do pensamento único à consciência universal. 9. ed. Rio de Janeiro: Editora Record, 2002.

SÃo PAULO (Município). Relatório realizado pela Comissão de Melhoramento do Rio Tietê. São Paulo, 1950.

SEABRA, Odette Carvalho de Lima. Os meandros dos rios nos meandros do poder: o processo de valorização dos rios e das várzeas do Tietê e do Pinheiros na cidade de São Paulo. 1987. Tese (Doutorado em Geografia) - Faculdade de Filosofia, Letras e Ciências Humanas, Universidade de São Paulo, São Paulo, 1987.

SILVA, Diana Mendes Machado da. Entre o ethos aristocrático e o associativismo: fu tebol amador e competência esportiva na cidade de São Paulo (1920-1930). História Unisinos, São Leopoldo, v. 19, n. 3, p. 293-302, 2015. DOI: 10.4013/htu.2015.193.03. SOMEKH, Nadia; CAMPOS, Candido Malta (org.). A cidade que não pode parar: planos urbanísticos de São Paulo no século XX. São Paulo: Editora Mackenzie, 2002.

TOLEDO, Benedito Lima de. Prestes Maia e as origens do urbanismo moderno em São Paulo. São Paulo: Empresa das Artes, 1996. 


\section{Denise Falcão Pessoa}

Centro Universitário Belas Artes de São Paulo, Curso de Arquitetura e Urbanismo

Rua Dr. Álvaro Alvim, 90, São Paulo, SP, Brasil, CEP 04018-010

CV: http://lattes.cnpq.br/9490051292702037

Orcid: https://orcid.org/0000-0003-1828-9423

E-mail: denisefpessoa@hotmail.com

\section{Nota do Editor}

Revisão do texto: Tikinet

Submetido em: 03/06/2019

Aprovado em: 20/09/2019 